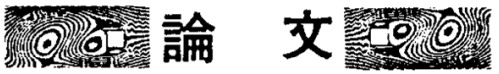

\section{低ライズケーブル補強空気膜構造の構造特性と耐風設計 Structural characteristics and wind resistant design of low-profile cable-reinforced air-supported structures}

\author{
岩佐義 輝 ${ }^{*}$ 又義浩 ${ }^{* *}$ 梁尾康 三 ${ }^{* * *}$ 岡田蔁** \\ Yoshiteru IWASA Yoshihiro MATAKI Yasuzo FUKAO Akira OKADA
}

\section{SUMMARY}

In general, air-supported structures are designed primarily against wind load which causes the greatest stresses in the environmental condition.

Furthermore, the wind pressure distribution is variable and extremely complex in contrast to the load caused by internal pressure or dead load.

This paper deals with following wind resistant characteristics of low-profile cablereinforced air-supported structure.

1) The structural characteristics based on results of wind-load loading tests and periodically forced vibration tests by using a large-scale model.

2) Wind pressure distribution of the roof measured in the field-test and the wind tunnel tests.

3) The analytical determination methods of wind toad and dynamic deformation of the roof.

1.はじめに

空気膜構造は、博臨会のパビリオンあるいはス ボーツ施設などの建築物として数多く建設されて きたが，それらは，耐風性および耐久性に関し， 怛久侓築物として必ずしも十分な性能を保有して いないととから仮設建築物に限られていた。1)

しかし, David H.Geigerによる耐風性の高い 低ライズケーブル補強空気膜構造システムの開発
と，強度，耐久性共に高い四ふっ化エチンン樹脂 をコーティンクしたガラス䋐維布の開発により， 本構法による空気膜構造は但久建築物としての性 能を有するにいたり，米国においては多くの大規 模な空気膜構造建築物が建設され，すでに 10 年 の実績を有している。

国内においても，昭和 59 年に小規模ではある が，恒久建築物として第 1 号の空気膜構造建築物

*竹中工務店技術研究所主任研究員 $* *$ 同 左 $* * *$ 竹中工務店技術研究所研究員 $* * * *$ 同 左

Technical Research Laboratory Takenaka Komuten Co., Ltd Chief Research Engineer (*,**)

Research Engineer (***,****)

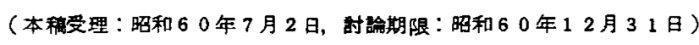


が建設され(霊友会弥勒山エアードーム)，また その後，日本建築センターにおいて，室内野球場 などを対象とした大規模空気膜構造による恒久建 築物の調查研究が行われ，評洒基準 ${ }^{2}{ }^{2}$ が作成され た。今日では，その評価基準に基き，スパンが $200 \mathrm{~m}$ 規模の大規模な空気膜構造の建設 (後楽園 エアート゚ーム)功進められるにいたっている。

空気膜構造の耐風設計関する研究は，川村等 $\left.{ }^{3}\right)$ により，高ライズの空気膜構造に関するあのが多 く報告されている。本報告の対象とする低ライズ ケーブル補強空気膜構造については，EXPO’70 のアメリカ館において，仮設建築ではあるが 100 $\mathrm{m}$ を超えるスバンの構造物が初めて奉現しそその 際，その而風性に関する研究が川村等）に上り報 告されている。しかし，その後この構造の耐風性 に関する研究は少く，B.V.Tryggvason ${ }^{5}$ による 風洞実験手法に関する研究が一部見られるにすぎ ず，また，そてで提案されている風洞実験の相似 則は必ずしも本構造の動力学特性に裏つけられた あのではない。

このようなととから，筆者等は，他の構造物と 同等の強度，耐久性を有する但久建筑物としての 空気膜構造の耐風設計手法を検討するため, 大規 模な試験体による野外実験や風洞実験および耐風 伈答解析などを行い，各種データの蓄積を計って きた。

本報告では，本構造の耐風設計に関連する構造 特性 (静力学特性, 動力学特性. 強風時の振動性 状 ）および屋根面に作用する風圧力の分布性状に ついて述へる。また，それらのデータに基ついた 本構造の耐風設計の概要および耐風設計に際し基 本となる風荷重と変形の算定方法について報告す る。

\section{2. 構造特性}

2.1 風荷重載荷実験による静力学特性 低ライズケーブル補強空気膜構造のスパン約
$25 \mathrm{~m}$ の大規模な試験体 (以下大規模試験体 ${ }^{7}$ ) 8 ) と略す)を用い载荷実験を行い静力学特性を調べ た。

大規模試験体は，スパン $125 \mathrm{~m}$ の計画建物 (Fig.2.1) を静力学的相似条件に基づき約 $1 / 5$ に 縮小したモデル(Fig.2.2)である。

屋根面境界部に設置したコンブレッションリン グは常時内王 ( $25 \mathrm{~mm} \mathrm{Aq})$ 時に曲げモーメントが 最小となる funi cular 形状をしている。

膜材はグラスファイバーで織られた基布に四フ ッ化エチレン樹脂をコーティンクした材料を用い (Table-2.1 ),アルミ型材, クロロプレンゴム, クランプ等を用いてケーブルに取りつけている。 ケープルはストランドロープを使用し(Table -2.2 )、ケープル相互はUボルトを用いた摩擦止 めクランプにより緊結した（Fig.2.3）。また，ケ ーブル端部の定着には区縮止めを用い，鉛直方向 の挙動に対してピン支承とし、コンプレッショリ ンクにアンカーしている(Fig.2.4)。なお, 本試

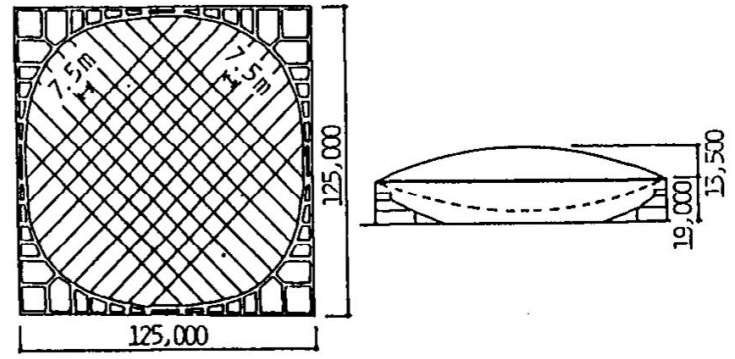

Fig.2. 1 計画建物

(Air dome plan)

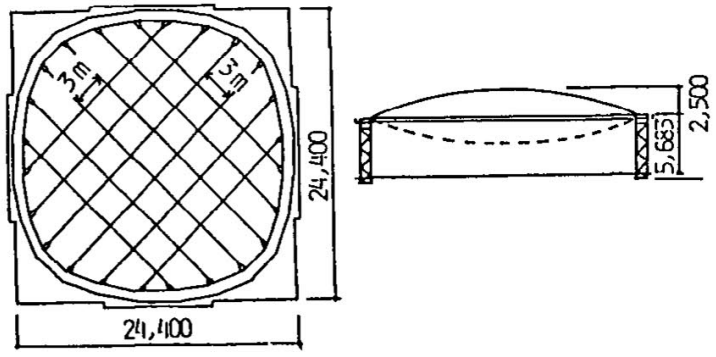

Fig.2.2 大規模試験体

(Large-scale model in the field) 
Table.2.1 膜材の材料定数

(material properties of membrane)

\begin{tabular}{|c|c|c|}
\hline 名称 & Teflon-coa & d tiberglass \\
\hline 所面 白 & & $0.8 \mathrm{~m}$ \\
\hline 単位重量 & & $1.27 \mathrm{~kg} / \mathrm{m}$ \\
\hline \multirow{2}{*}{ 碎断強度 } & 路系方向 & $150 \mathrm{~kg} / \mathrm{cm}$ \\
\hline & 椣采方向 & $120 \mathrm{~kg} / \mathrm{cm}$ \\
\hline \multirow{2}{*}{ 引張明性 } & 系方向 & $1540 \mathrm{~kg} / \mathrm{cm}$ \\
\hline & 横手方向 & $680 \mathrm{ke} / \mathrm{cos}$ \\
\hline
\end{tabular}

験体の屋根面の平均重量は約 $10 \mathrm{~kg} / \mathrm{m}^{2}$ である。

本溝造の静力学特性を把握するための風荷重分 布の再現にあたっては，風洞実験結果から得られ た最大風圧係数に相当する上向きの荷重を内圧

（内部と外部の静圧の差を内圧と略す）により与 え，過大に載荷された部分に対しては最大風圧係 数と各点の風圧係数の差に相当する力を重鏵によ り下向きに与える方法を採用した (Fig.2.5)。 加力用風圧係数分布 (Fig.2.6) は, 風洞実験加 ら得られた風圧係数 (Fig.3.4)を各交点ごとの負 担面積で平均化して求めた。

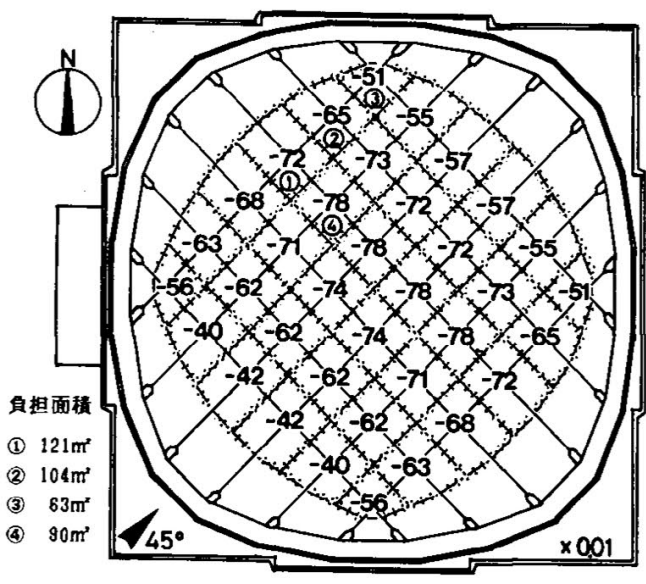

Fig.2. 6 加力用風圧係数分布 (風向角 $45^{\circ}$ ) (Distribution of wind pressure coefficients for loading, $\theta=45^{\circ}$ )
Table.2.2 ケーブルの材料定数

(material properties of cable)

\begin{tabular}{|c|c|}
\hline 名 & 7×37共芯ローフ7 \\
\hline 啋 & \\
\hline 往（断面积） & $\phi 25\left(313 \mathrm{~cm}^{2}\right)$ \\
\hline 単位蒠量 & $260 \mathrm{~kg} / \mathrm{m}$ \\
\hline トンケ保坟 & $14,000 \mathrm{~kg} / \mathrm{ms}^{2}$ \\
\hline 引还强度 & $39.1 \mathrm{t}$ \\
\hline
\end{tabular}

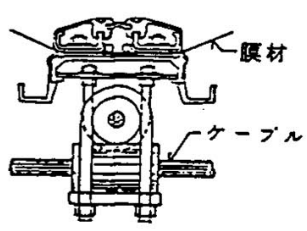

Fig.2. 3 ケーブル交点詳細

(Cable intersection)

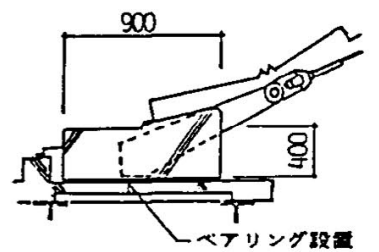

Fig.2. 4 ケープルアンカー詳細

(Cable anchor to compression ring)

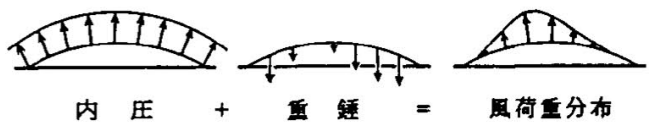

Fig.2.5 風荷重分布の再現方法 (Wind load concept) 
Fig.2. 7 亿内压 $25 \mathrm{~mm} \mathrm{Aq}$, 速度压 $140 \mathrm{~kg} / \mathrm{m}^{2}$ 時の屋根面形状およびヶーブル端部張力について,

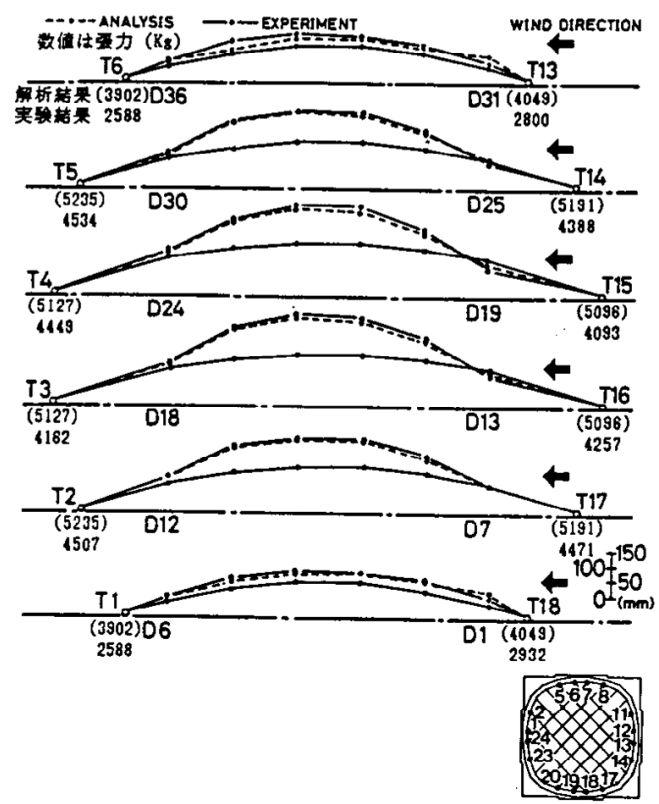

Fig.2.7 変形形状およびヶーブル端部張力 ( 風向角 $45^{\circ}$, 速度王 $140 \mathrm{~kg} / \mathrm{m}^{2}$ ) (Roof deflection and Cable-end tensions, $\left.\theta=45^{\circ}, \mathrm{q}=140 \mathrm{~kg} / \mathrm{m}^{2}\right)$

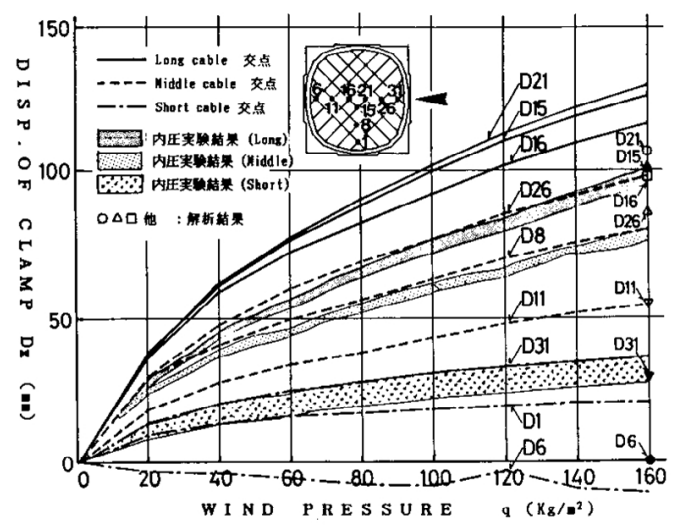

Fig.2. 8 速度压之交点変位の関係 (風向角 $0^{\circ}$ )

(Relation between deflections and wind pressure)

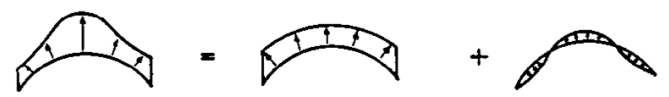

Fig.2.9 風荷重の分布状態

(Component of wind loading)
実験結果之解析結果を併せて示す(風向角 $45^{\circ}$ ) 風荷重はFig.2.6亿示されているように全面負圧 であるが、不均等分布であるため，変位は荷重分 布方向と逆の下向きに生じている部分がある。一 方, 張力は速度王にほぼ比例しており（Fig.2.10）, 不均等分布荷重にかかわらず, 同一クーブル両端 では同程度の張力值を示している。

荷重分布形状の違いが変形性状に及ぼす影餗を 把握するため，風荷重を等価な等分布荷重に置換 して得られた結果 (内压実験結果)をハッチで本 実験結果上に示す (Fig.2.8)。風荷重時の変形は, 周辺部を除き等分布荷重に換算した時の変形と比 較してかなり大きい。乙れは模式図 (Fig.2.9)に 示す上うに，風荷重分布には等分布荷重に加えて

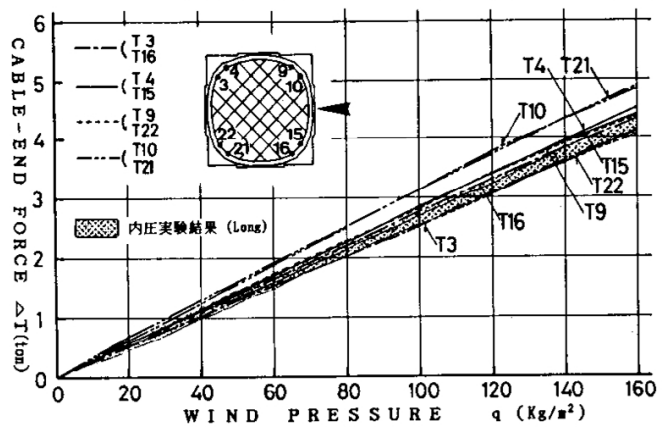

Fig.2.10 (a) 速度王とケーブル端部張力の関係 (風向角 $0^{\circ}$, Long Cable)

(Relation between cable-end tensions and wind pressure)

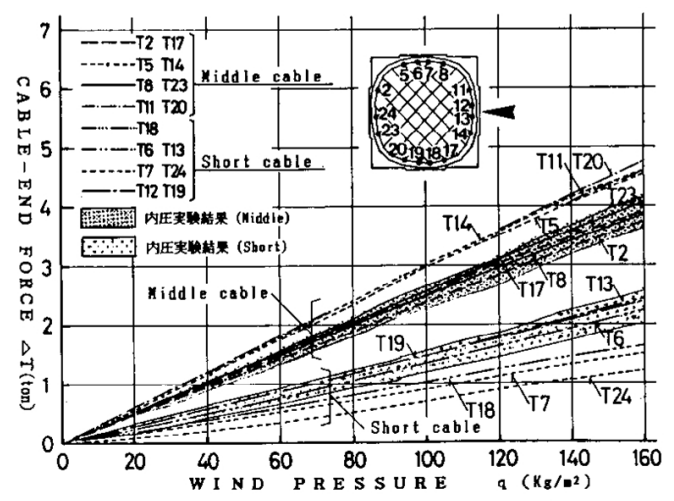

Fig.2.10 (b) 速度王とケーブル端部張力の関係 (風向角 $0^{\circ}$ Middle \& Short Cable) (Relation between cable-end tensions and wind pressure) 
変形の生じやすい分布形状 (変形に比へ張力変化 が小さい)の荷重が付加されているためである。

同樣にヶーブル端部張力に関して，平均風压係 数に基づいて換算した内压実験結果を本実験結果 と共に示す(Fig.2.10)。風荷重時の張力は絶対 值の小さい short ケーブルを除けば，等分布荷重 に換算した張力の100〜122\%の幅に包括され ている。との幅は交点変位と比較して小さく，荷 重の偏在性がケーブル張力に及ぼす影整は少ない といえる。

\section{2 強制人力加振実験任よる動力学特性}

構造体の動力学特性を把握するために行う振動 実験には各種の方法があるが、小さな力を繰り返 し与えるととによって容易に振動をさせるととが できる本構造の特徽を利用して人力による強制振 動実験を行つた。

大規模試験体において，Fig.2.11 亿示す解析 モードを再現するため，・印の個所に人を配置し、 正弦波発生装置の周期任合わせ、ケーブル交点よ り市り下げたワイャーを引っ張り瞬時に離すとと

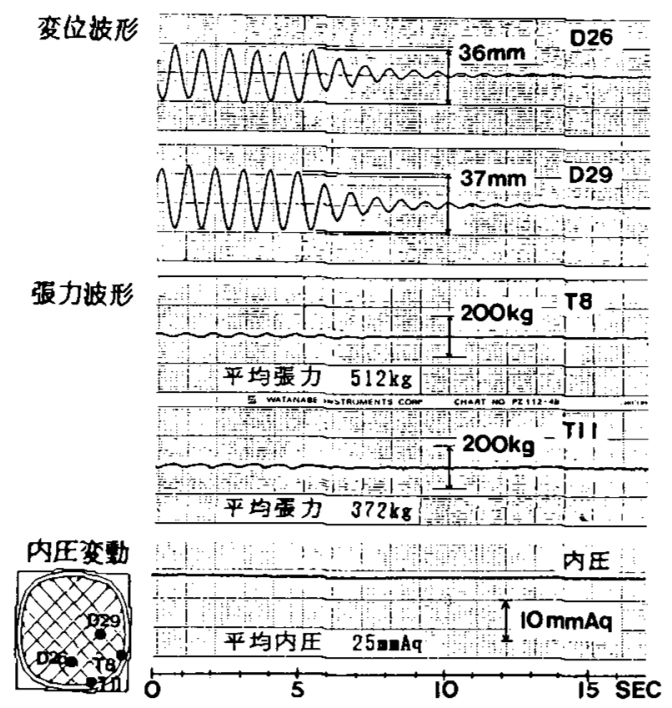

Fig.2.12 振動波形 ( 1 次モード)

(Free vibration waves of deflections, tensions and internal pressure for lst mode)
を繰り返し行う万法で起振し, 安定振動が得られ た時点に加振を止め, 目由振動を測定した。

1 次, 2 次モードに関する共振時の変位, 張力 波形および内压変動をFig.2.12，2.13 亿示す。 1 次モードにおいては测定点D26 2D29の変位 が，2次モードではD 5 とD 16 の変位が逆位相 になっており，解析で得られた振動モードが再現 されている。この振動モードでは、ケーブル端部 張力は近接した交点の变位波形と同位相となって

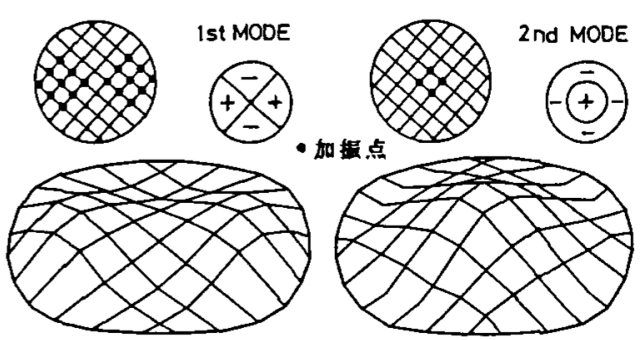

Fig.2. 11 固有モードと加振位置 (1st and 2 nd mode configurations and forcing points for free vibration test )

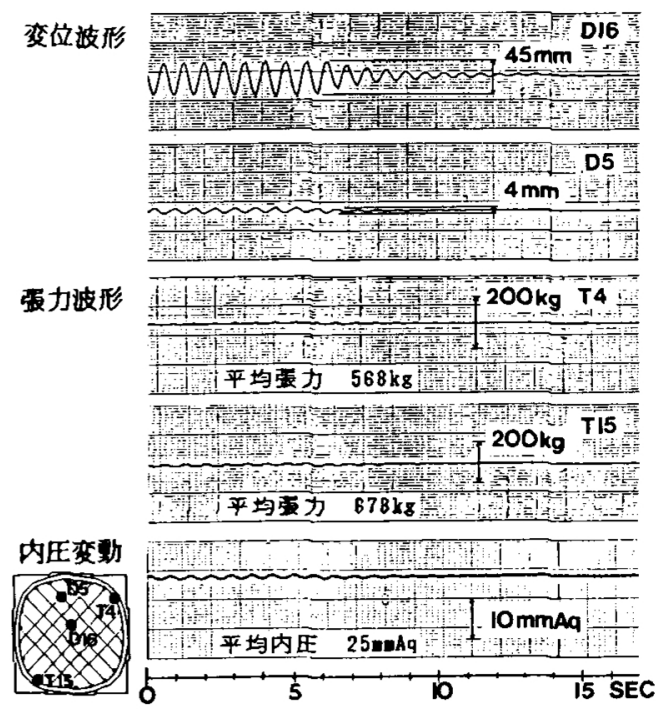

Fig.2.13 振動波形（ 2 次モード）

(Free vibration waves of deflection, tensions and internal pressure for 2nd mode) 
Table.2.3 固有振動数 $(\mathrm{Hz})$

(natural frequencies)

\begin{tabular}{|c|c|c|c|c|}
\hline 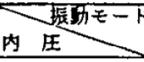 & 1 st & $\tau-F$ & 2 nd & $E-r$ \\
\hline $25 \mathrm{mmAq}$ & 1.06 & $(0.92)$ & 1.43 & $(1.24)$ \\
\hline 35 muAq & 1.36 & $(1.20)$ & 1.58 & $(1.67)$ \\
\hline $50 \mathrm{mmAq}$ & 1.62 & $(1.53)$ & 1.92 & $(2.11)$ \\
\hline
\end{tabular}

Table.2.4 减衰定数 (\%)

(Damping coefficients)

\begin{tabular}{|c|c|c|}
\hline 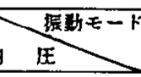 & 1 st $\varepsilon-r$ & 2 nd $E-F$ \\
\hline $25 \mathrm{mmAq}$ & $6.0 \sim 7.0$ & $4.5 \sim 5.0$ \\
\hline $35 \mathrm{mmAq}$ & 5.4 & $3.8 \sim 4.0$ \\
\hline $50 \mathrm{mmAq}$ & 4.2 & 3.6 \\
\hline
\end{tabular}

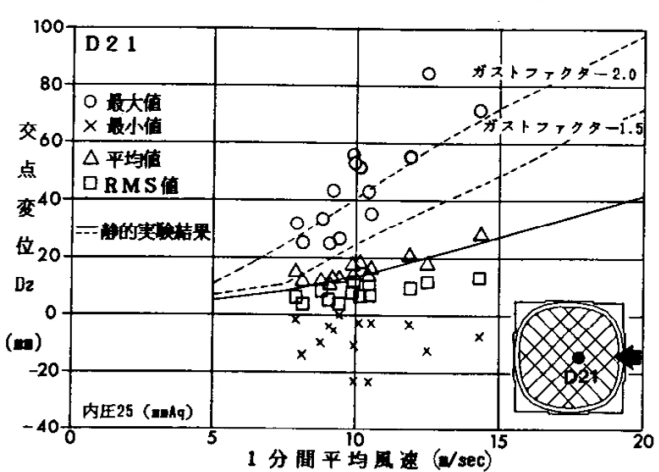

Fig.2.14 平均風速と交点変位の関俰

(Relation between deflections and mean wind speed)

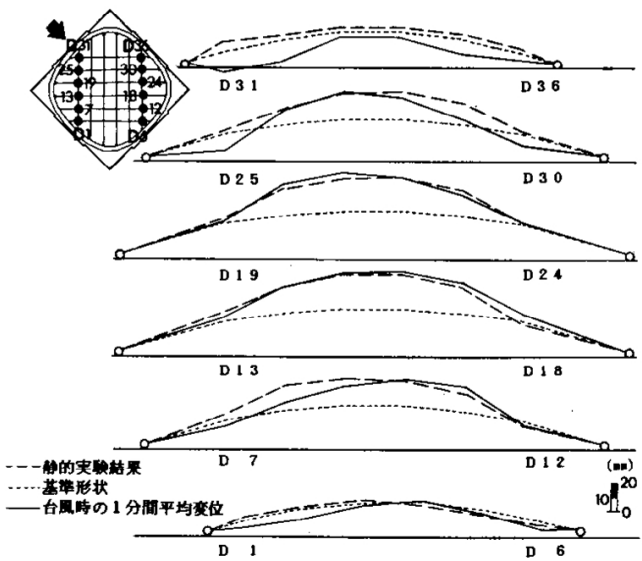

Fig.2.15 台風時の平均的形状之静的実験結果の 比較

(Mean deflection during typhoon and results of static loading test)
いるが，風荷重載荷実験で得られた強制的な荷重 に対する張力の変化と比較すると，その変化量は 非常に小さい。一方，内压変動は 1 次モードでは 認められず，2 次モードにおいてやや認められる あのの, その変化量は極めて小さい。これらのと とから，モード振動は体積変化を伴わない振動で あり，ケーブル張力に与える動的効果は少ないと 考えられる。

Table-2.3，2.4にと机らの波形より求めた回 有振動数および減衰定数走す。減哀定数は速度 比例型の减衰振動之仮定して変位振幅比より求め た。固有振動数は内圧の増加に伴い徐々に大きく なり，特に 1 次固有振動数は付加内圧 (内圧 - 自 重 ） $1 / 2$ 乗にほぼ比例して増加している。

一方，減衰定数は内压の增加化伴い減少してお り，さらに2次のモードの方が小さくなっている。 2.3 強風時の振動性状

台風 8218 号の強風の継続時間はおおむね 2 時 間程度であったが( 1 分間平均風速 $7.2 \mathrm{~m} / \mathrm{s} \sim 14$. $9 \mathrm{~m} / \mathrm{s}$, 最大瞬間風速 $30.6 \mathrm{~m} / \mathrm{s}$; 軒高位置 ), そ

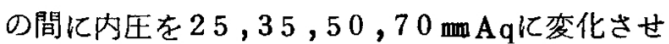
屋根面の変位, ケーブル張力等の動的なデータを 測定することができた。

Fig.2.14 亿内压 $25 \mathrm{~mm} \mathrm{Aq}$ 時のケーブル交点 変位の最大値, 最小值, 平均値, 標準偏差と 1 分 間平均風速の関係を示す。図中，実線扰よび破線 は平均風速あるいはガストファクターを考虑して 換算した荷重に対応する静的風荷重載荷実験結果 である。台風時の平均変位は静的載荷実験結果に ほぼ一致している。ての傾向をより詳細に把握す るため, ある一定平均風速 $(15 \mathrm{~m} / \mathrm{s})$ 下での屋根 面全体の両者の変位を比較した（Fig.2.15)。屋 根周辺部において若干の差が認められるが, 全体 の変形形状は招おむね一致しており，台風時の屋 根面変位の平均值成分は静的実験あるいは静的解 析ブログラムを用いて十分推定できるすのと考え られる。一方，最大交点変位を最大瞬間風速に対 


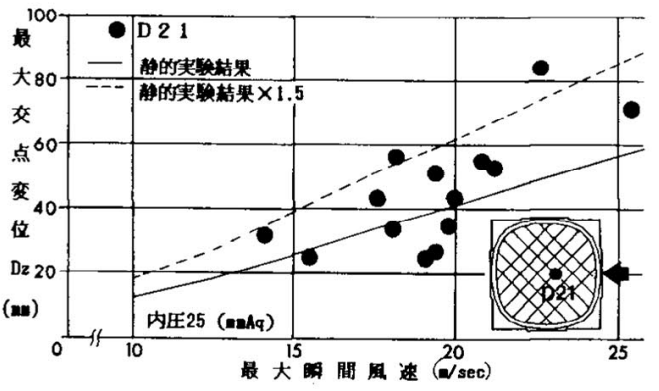

Fig.2. 16 最大瞬間風速之最大交点変位の関係 (Relation between maximum deflections and gust wind speed)

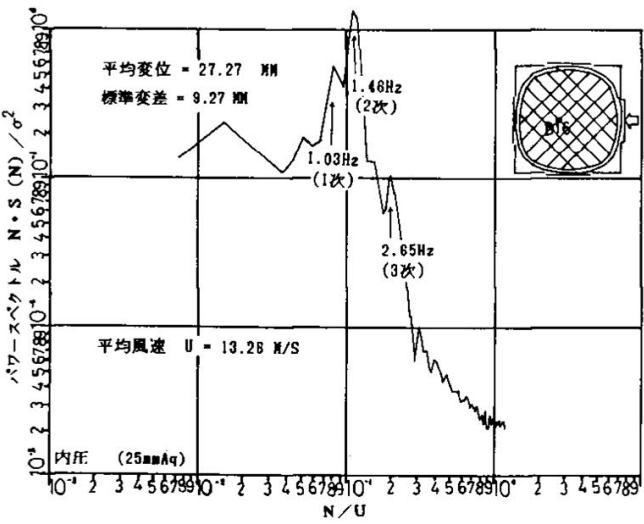

Fig.2.17 交点変位のパワースペクトル

(Power spectrum density of deflection)

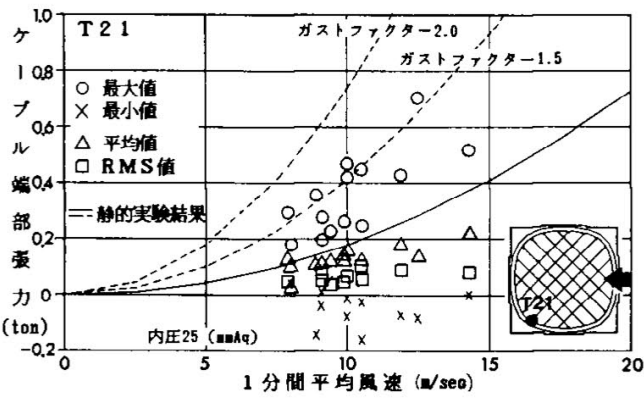

Fig.2.18 平均風速とケーブル端部張力の関係 (Relation between cable tensions and mean wind speed)
し示すと (Fig.2.16)，その平均值は静的実険結 果により，またその上限值は静的実験結果の 1.5 倍の関係としてほぼ示すととができる。次に㕠位 の周波数特性を分析すると、低次のモードが卓越 した振動性状を示しており，強風時の挙動はヶー ブル長の変化を伴わない（体積変化の伴わない） 振動が主であるととがわかる(Fig.2.17)。

次に，風速とケーブル端部張力の関係をFig。

$2.18,2.19$ 亿示す。それぞれの張力値は，初期 のケーブル張力の差異をなくすため, 测定結果よ り内圧 $25 \mathrm{~mm} \mathrm{Aq}$ の無風時の張力を差し引いてい る。平均風速とケーブル端部張力の関係では，平 均張力は静的載荷実験結果之, 最大張力はガスト フォクターを 1.5 とした場合の静的藏荷実験結果 とほぼ一致している。また，最大瞬間風速と最大 ケーブル張力の関係では，実測結果は静的載荷実 験結果より大きく下回った値を示している。とれ らから，平均風速に相当する平均張力は生じるが， 張力変動は交点変位と比較して小さく，前述した 強風時の挙動が主にケーブル長の変化を伴わない （体積変化の半わない）振動であるととを裏づけ ている。

これらの結果から明らかなように，暴風時に内 压を常時内断（25 m Aq 3 $0 \mathrm{~mm} \mathrm{Aq} ）$ のまま保

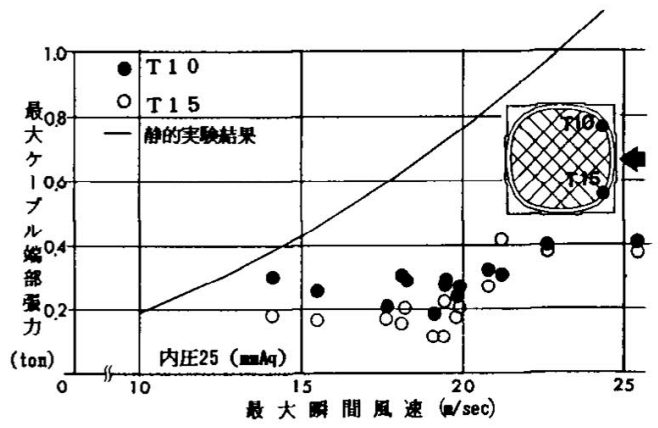

Fig.2.19 最大瞬間風速と最大ケーブル端部張力 の関係

(Relation between maximum cable tensions and gust wind speed) 
持した場合，大きな振動が発生することが予想さ れ、使用上不安感を与え好ましくない。このため， 内王を高め屋根面の振動を抑制する方法が考えら れるが，その効果を定量的に把握するととが必要 である。Fig.2.20は内压 $25,50,70 \mathrm{mmAqTV}$

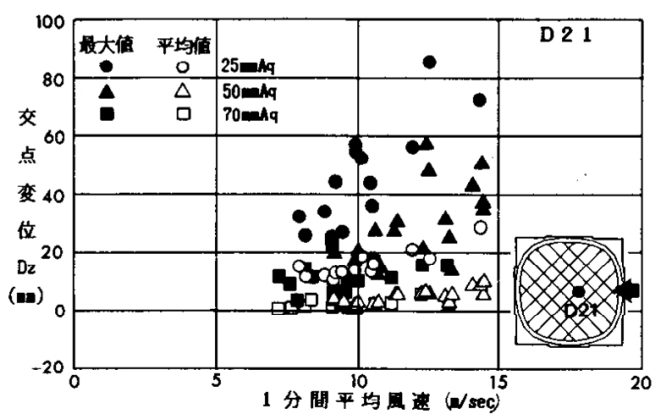

Fig.2.20 各内压下における交点変位の比較 (Relation between deflections and internal pressure)

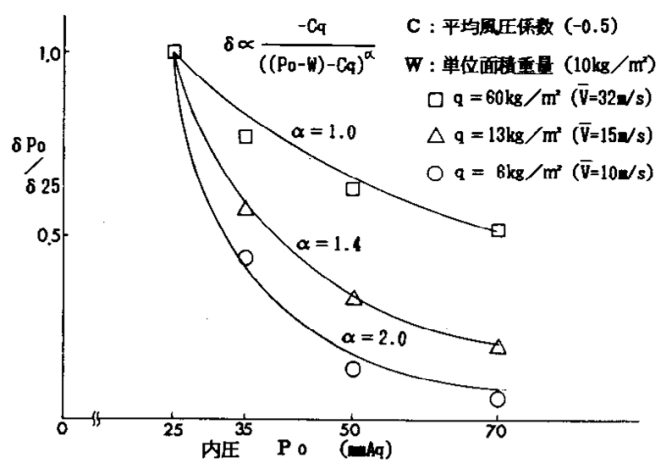

Fig.2. 21 平均変位に対する内王の勃果

(Effect of internal pressure for mean deflection)

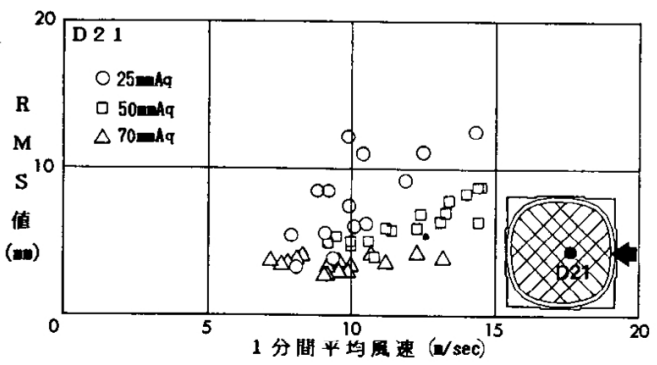

Fig.2. 22 各内王下に打矿交点変位のR.M.S值

(Relation between dynamic deflections and internal pressure)
おりる中央測定点の変位の最大値, 平均值を比較 した図である。これらのデータを用いて，内圧 25 $\mathrm{m} \mathrm{Aq}$ 下の平均変位に対する各内压下の平均変位 の比をとりFig。2.21 亿示す。なお， $q=60 \mathrm{~kg} / \mathrm{m}^{2}$ $(\overline{\mathrm{V}}=32 \mathrm{~m} / \mathrm{s})$ のデータは静的な風荷重載荷実験 より得られた平均変位の比である。また，図中実 線は剛性が平均風速の大きさに応じて変化すると 仮定し，風圧力のパラメータを剛性に含めた近似 式を用いて，実験值に適合するように影䇺係数 $\alpha$ を決定した曲線である。図より，低風速の場合， 変形は内任之風荷重の和の 2 乗に反比例して低下 するが，風速の増加に伴い影譬係数 はは 1 亿近つ く傾向にある。このように，低風速ほど平㚬変位 に対する内圧上昇効果は顕著であるが、設計風速 レベルの高風速に扔いても, 内压を $60 \mathrm{mmAq} に$ 升王すれば変形を常時内王時の $50 \%$ 程度に抑制 することが可能である。一方，各内压下の变位の RM S 值をFig.2. 22 に示す。測定結果にバラッ キがあり，十分な把握は困難であるが，おおむね RM S 值は付加内圧 (内圧加自重を减じたもの) の $1 / 2$ 乗に比例して小さくなる傾向にある。

\section{3. 風圧力の分布性状}

大規模試験体の䊒尺 $1 / 50$ に相当する剛体模型 （Fig.3.1）を用い，屋根面に凹凸がある本構造物 に作用する風圧力の基本性状を風洞実験により把 握するとともに，台風時の実測結果と比較検討し た。年また，スパン $200 \mathrm{~m}$ 規模を対象とした模型 （屋根面の凹凸を無視した縮尺 1 /500 の模型Fig. 3.2 )を用い, 屋根面のライズ・スパン比および 屋根面全体の勾配の影響に関し, 風洞実験より検 討した。なお，実験で用いた風洞気流は指数 $1 / 4$ の境界層流である( Fig.3. 3 )。

Fig.3. 4 亿風向角 $0^{\circ}$ およ゙ $45^{\circ}$ の大規模試験 体を対象とした模型の平均風王係数分布を示す。 図より屋根面には全面に負圧が作用し，その大き さは，屋根面中央部近傍では $-0.7 \sim-0.9$ 程度であ 


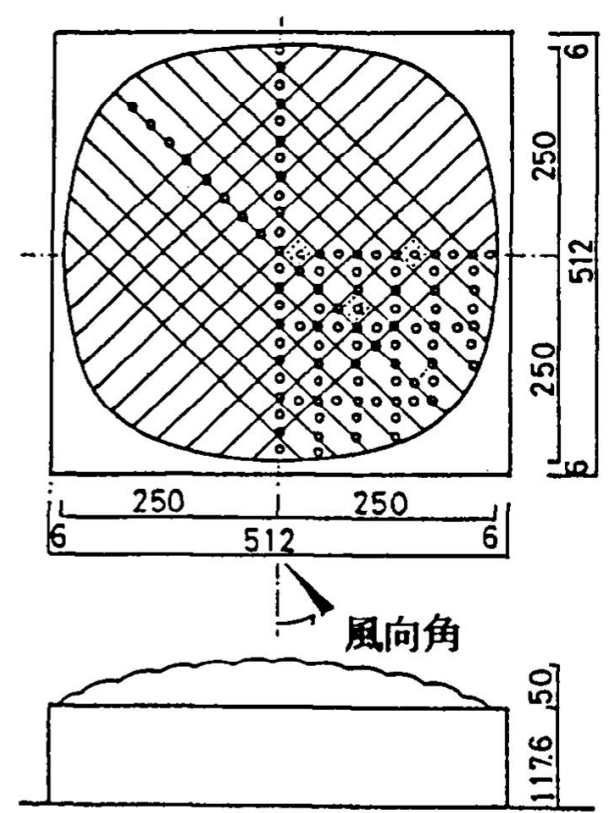

Fig.3.1 模型および測定点（単位m）

(Rigid model used in the wind tunnel test and measuring points)

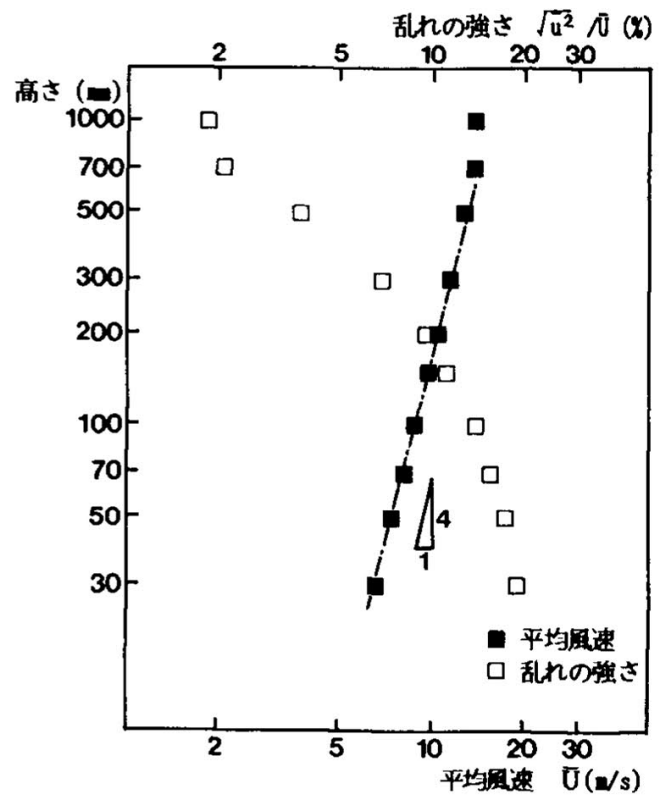

Fig.3.3 風洞気流の平均風速および乱れの強さ の鉊直分布

(mean velocity and intensity of the longitudinal fluctuation of wind tunnel flow)

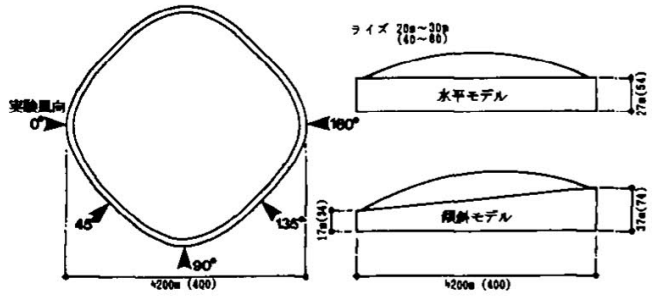

Fig.3. 2 模型概要（）内性型す法口 (Rigid model used in the wind tunnel test)

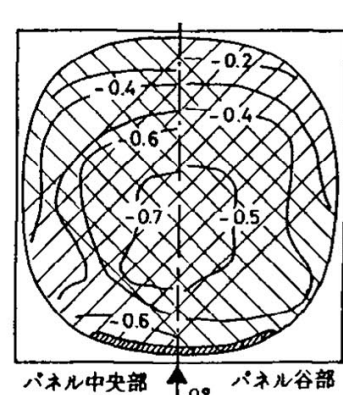

（b）風向角 $0^{\circ}$

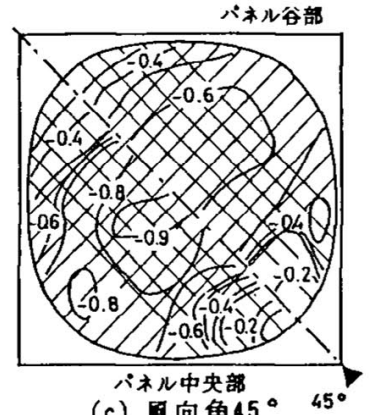

(c) 風向角 $45^{\circ}$ (1200 -1.0 を䖯元万敛姑
Fig.3.4 平均風厈係数分布

(Distribution of mean pressure coefficients)

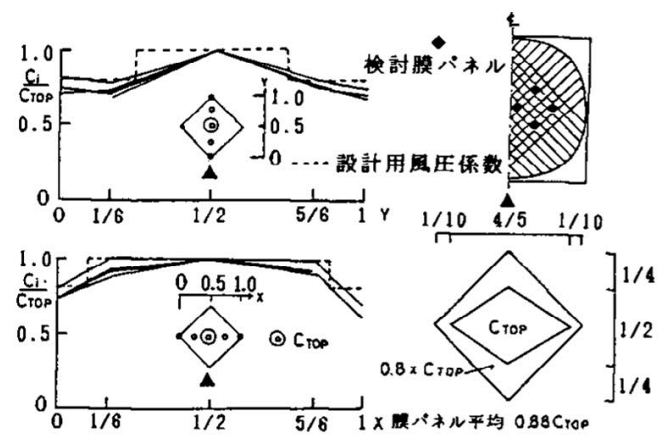

Fig。3.5 膜パネル内風圧係数分布

(Distrilution of mean pressure coefficients in panel)

る。局部負圧に関しては，風上側端部で最大 -1 . 35 (風向角 $0^{\circ}$ )の値を示したが, 一 1.0 を超え る領域 (図中斜線) は極めて小さい。

屋根面に凹凸のある空気膜構造の特徵として, 膜パネル中央部の風圧係数の絶対值がケーブル位 置に相当する谷部での値より大きくなる傾向が伺 える。Fig.3.5 は，膜パネルに作用する風圧係数 
の分布を各膜パネルの中央部での風王係数で無次 元化して示したあのである(風向角 $0^{\circ}$ )。膜パネ ルに作用する風圧力は，中央部が最大で谷部が最 小の䖵王分布となっており，膜パネル全体に作用 する平均的な風压係数は中央部の 0.88 倍とみな せるととがわかる。同様䖝向角 $45^{\circ}$ の場合には 0.825 倍となる結果を得ている。

次飞, 昭和5 7 年9月12 日の台風8 218 号 に伴う強風時に夷測した大規模試験体の平均風圧 係数分布拈よび中央測線上の風圧係数関する風 洞実験結果との此较をFig.3.6亿示す。目然風下 では，風向が $S \sim S S W$ 変化していることや，カ ストの大きさの違い，更に莫面の实出物(排煙ダ ンパー，庇等）の影響により，風圧分布性状はや や異なっているが，俰数値のオーダー讷風洞実験 結果上良い対応を示している。

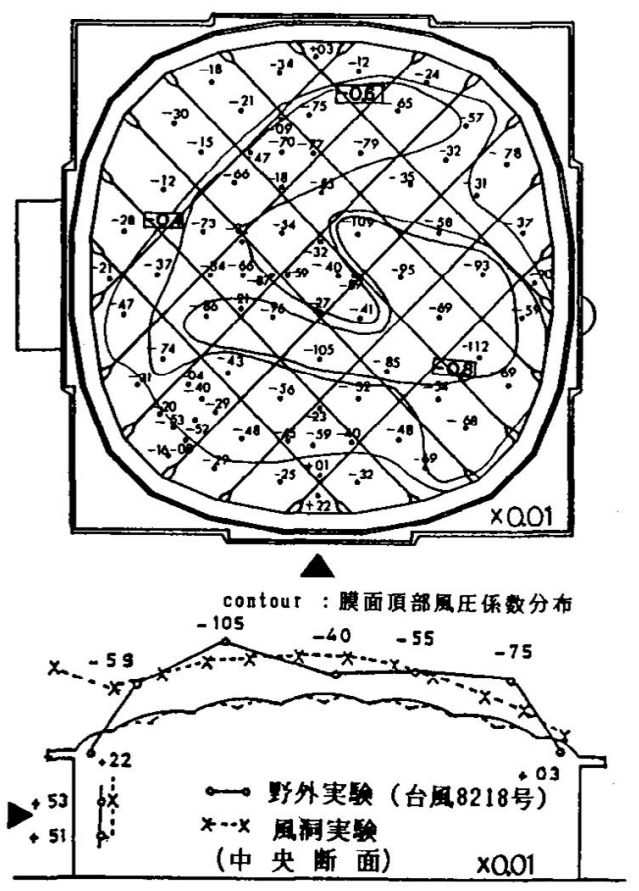

Fig.3.6 大規模試験体の台風時風压保数分布 (Distribution of mean pressure coefficients in field test during typhoon)
Fig.3. 7 に, スパン $200 \mathrm{~m}$ 規模を対象とした風 向 $0^{\circ}$ (大規模試験体モデルの $45^{\circ}$ に相当)，ライ ズ・スパン比 0.1 , 屋根勾配 $0^{\circ}$ の場合の平均風 王係数分布を示す。外周部の形状は大規模試験体 モデルとは異なるが，屋根面の風圧係数は膜ハネ ル中夫部の性状と類似したものとなっている。

次に，風の流れに沿った稜線部分の值を取り出 し, 風向 $0^{\circ}$, 屋根勾配 $0^{\circ}, 5.5^{\circ}$ 心場合について, ライズ・スパン比による相違をFig.3.8，3.9に 示す。平均風圧係数の分布は各ケース共風上, 風 下で値が小さ，中央で負生の大きな山型の分布 を示し，ライズ・スパン比が大きくなるはど最大， 最小風王係数の差が広がり分布の勾配急になる。 屋根勾配が有る場合，膜面頂部の位置は高層側へ 移動するため，風王力の分布も全体的に高層側へ 移行している。

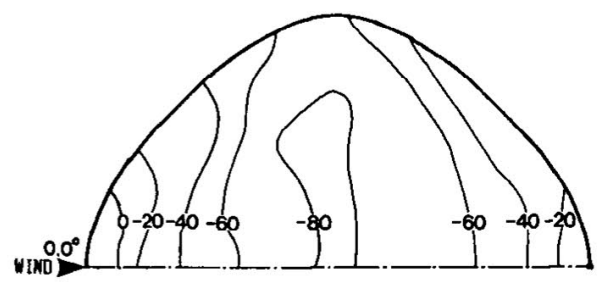

Fig.3. 7 屋根面に凸凹のない場合の平均風圧係 数分布

(Distribution of mean pressure coefficients in the case of considering without unevennss, $\theta=0^{\circ}$, $\mathrm{R} / \mathrm{S}=0.1$, roof slope $; 0^{\circ}$ )

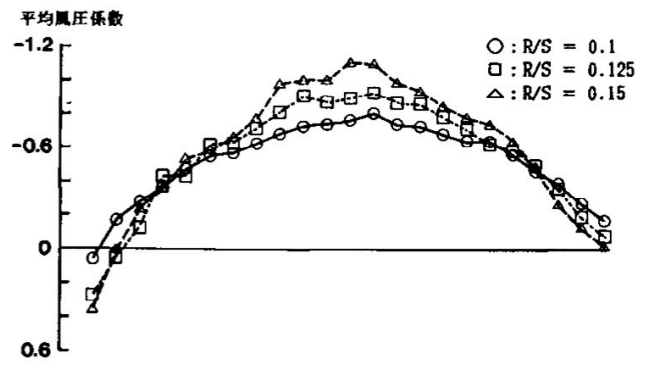

Fig.3. 8 平均風压係数分布 (風向：0.0 , 屋根 勾配：0.0 $0^{\circ}$ )

(Mean pressure distribution, $\theta=0^{\circ}$, roof slope:0.0\%) 
Fig.3.10 亿，屋根面全体に作用する風压力を 表わす指標として, 各平均風圧係数の総和より求 めた係数を風向別に示す。実験風向は $0^{\circ}, 45^{\circ}$, $90^{\circ}, 135^{\circ}, 180^{\circ}$ の 5 ケースであるが, 対称 形となる屋根勾配がない模型については $0^{\circ}$ と $45^{\circ}$ について示す。屋根勾配がない場合，風向による 大きな差は見られない。また，屋根勾配のある場 合風上の軒高が高いほど屋根面に作用する全体の 荷重は大きくなる傾向が見られる。風向 $0^{\circ}$ 亿比 較して風向 $180^{\circ}$ では最大約 $20 \%$ 程度增加して いる。

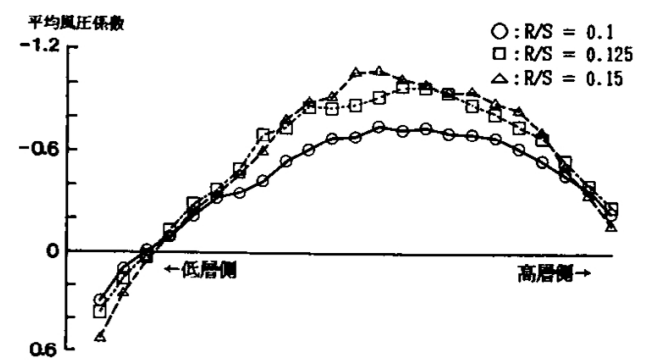

Fig.3.9 平均風圧係数分布 (風向： $0.0^{\circ}$, 屋根 勾配 $5.5^{\circ}$ )

(Mean pressure distribution, $\theta=0.0^{\circ}$, roof slope;5.5

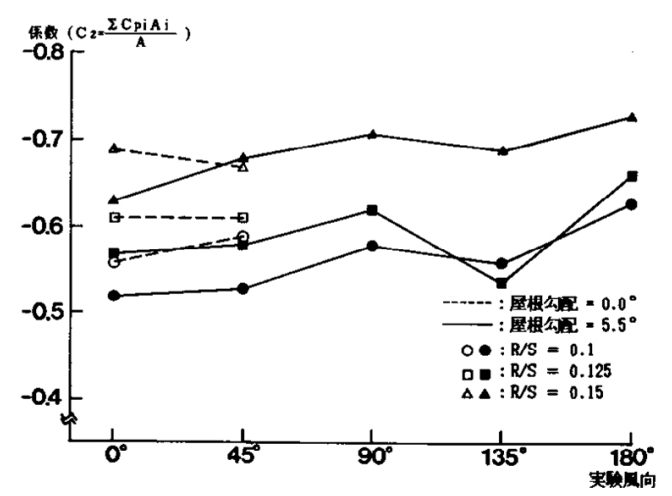

Fig.3.10 風向の違いによる膜面全体の平均風压 係数の比較

(Relation between mean pressure coefficients for whole roof and wind direction)

\section{4. 耐風設計}

\section{1 耐風設計の概要}

本構造の耐風設計のフローをFig.4.1 亿示す。 その中で，内圧の設定、変形の算定および破䧇確 率の算定は本構造特有の検討事項である。

2 章構造特性において述べたが，本構造は外力 に対し変形が比較的大きく生じる構造であり，ま たその剛性は内王に依存している。したがって， 本構造の耐風性は内匡制御システムによって維持 されるといってあ良い。

内压としては，風の弱い通常の気象条件下では 常時内王 ( $25 \sim 35 \mathrm{mmAq}$ 程度 )を, また, 強風時 には強風時内压として常時内圧より高い内王を設 定することが多い。乙の強風時内压は，強風時に おいても屋根面の振動変形が使用者の感覚などの 点で許容される範囲となるよう剛性を高める効果 を有している。使用者の感覚に関する許容振動変 形量については，現在定められたものはなく，変 形速度に対する知営の関係から許容傎を推定する

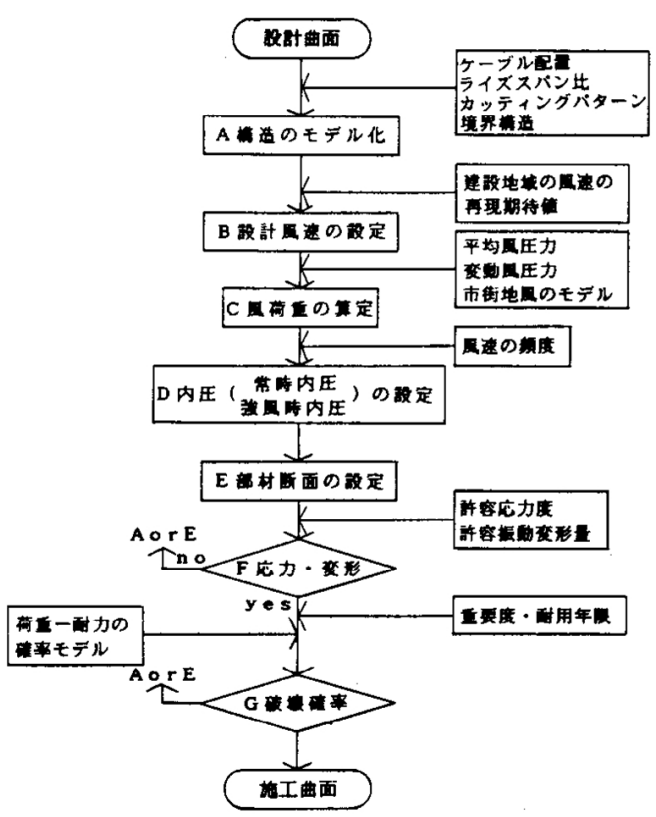

Fig.4. 1 耐風設計のフロー

(Flow chart of wind resistant design) 
方法などが考えられるが、今後の研究課題のひと つである。

このように内王は屋根の振動を减少させる有効 な作用をむつ反面，建物の出入口に生じる風速を 高めるなど，建物の使用性能汇影皘する。とのた め内圧が高い状熊では，バランスドアーの使用中 止等使用上の制限を設けなければならない場合が ある。したがって、強風時の内圧は大規模な建策 物では通常数段階にわたり設定される。

一力, 本構造浭用している膜材は, 強度の経 年変化が大きい等通常の構造材料とは異なる特殊 性をもち，また構造材料としての実績も少い。と のため膜材の安全率は必ずしも安全性の定量的な 指標になっているわけではない。とのととは，最 近の調査研究 $\left.{ }^{2}\right)$ においてあ指摘されており，耐風 設計において構造物の破壊確率あるい㹥安全性指 標などによる安全性の定量的な評価が必要である と考えられる。

次に，本構造の耐風設計上最も基本之なる風荷 重の算定および変形の算定方法について述べる。

\section{2 風荷重拉よび変形の算定}

1）ケープル設計用風荷重の算定

空気膜構造の基本的振動モードは，2.2，2.3 節で示したように内部体積の変化が少ないモード であり，てのようなモードで屋根面が振動しても， ケープルにはほとんど張力が付加されない。した がって, 屋根面の振動に関しては風荷重の分布性 状が大きく影響するが, ケーブル張力に関しては, 分布性状の影響は少なく，屋根面全体仁作用する 合力としての風荷重のみを訣価すればよい。

したがって, 屋根面全体に作用する平均風压力 $\mathrm{F}$ および変動風圧力 $\sigma_{f}$ は各々次式で表現できる。 ここでは屋根面を $\mathrm{N}$ 面素 ${ }^{4}$ 亿分割して考える。

$$
\begin{aligned}
& \mathrm{F}=\sum_{i=1}^{N} 1 / 2 \rho \mathrm{V}^{2} \mathrm{C}_{\mathrm{D} i} \mathrm{~A}_{i} \\
& \sigma_{f}^{2}=\int_{0}^{n_{0}} \mathrm{~S} f(n) d n
\end{aligned}
$$

$$
\begin{aligned}
& \mathrm{S}^{f}(n)=\sum_{i=1}^{N} \sum_{j=1}^{N} \rho^{2} \mathrm{~V}^{2} \mathrm{C}_{\sigma i} \mathrm{C}_{\sigma j} \mathrm{~A}_{i} \mathrm{~A}_{j} \mathrm{~S}_{i j}^{\mathrm{V}}(n)(3) \\
& \mathrm{S}_{i j}^{\mathrm{V}}(n)=\mathrm{S}^{\mathrm{V}}(n) \mathrm{R}_{i j}^{\mathrm{V}}(n) \mathrm{R}_{i j}^{\phi}(n) \\
& \mathrm{R}_{i j}^{\mathrm{V}}(n)=\exp \left(-k n \Delta r_{i j} / \mathrm{V}\right) \\
& \mathrm{R}_{i j}^{\phi}(n)=\exp (-j 2 \pi n \Delta \mathrm{X} i j / \beta \mathrm{V}), \\
& j=\sqrt{-1}
\end{aligned}
$$

ことに, $\rho$ : 空気密度, $\mathrm{A}$ : 面積, $\mathrm{V}$ : 基準点 平均風速, $\mathrm{C}_{\mathrm{D}}$ : 平均風王係数, $\mathrm{C}_{\sigma}$ : 変動風王係数, $\Delta r$ : 挋離, $\Delta \mathrm{X}$ : 風方向距離, $k, \beta^{10)}$ : 定数, $\mathrm{S}^{\mathrm{V}}(n)$ : 基準点の風速のスペクトル, no: 積分上 限周波数,サフィックスは面素を示す。

また，変動風王係数関しては，

i）各点の压力変動を自然風の乱れ成分で説明可 能な成分と、それに無相関な成分とからなる確 率過程と仮定し，直交原理を用いて期待値とし て評価する方法

ii）準静的理論を適用し, 圧力変動が完全に風速 変動に追従すると仮定し平均風王係数を使用す る方法 が考えられる。変動係数は各々，次式となる。

前者 $\mathrm{C}_{\sigma_{i}}=1 / 2 \mathrm{R}_{i} \mathrm{C}_{\sigma_{i}}^{*} / \mathrm{I}$

後者 $\mathrm{C}_{\sigma i}=\mathrm{C}_{\mathrm{D} i}$

ここに, $\mathrm{R}$ : 気流と压力の相関係数， I : 気流 の乱れ強さ， $\mathrm{C}_{\sigma}^{*}$ : 基準速度正で無次元化された 変動風圧係数

なお, 風荷重の最大値 $F \max$ は, 極值理論 ${ }^{11)}$ 用いて次式により評価することができる。

$$
\begin{aligned}
& \mathrm{Fmax}=\overline{\mathrm{F}}+\mathrm{P} \sigma_{f} \\
& \mathrm{P}=\sqrt{2 \ell n \nu \mathrm{T}}+0.5776 / \sqrt{2 \ell n \nu \mathrm{T}} \\
& \nu=\sqrt{\int_{0}^{n_{0}} n^{2} \mathrm{~S}^{f}(n) d n / \int_{0}^{n o} \mathrm{~S}^{f}(n) d n} \\
& \text { 乙こに, } \overline{\mathrm{F}}: \text { 平均風荷重, } \mathrm{T}: \text { 継続時間 }
\end{aligned}
$$
次に, 本風荷重算定式を大規模試験体に適用し, 台風 8218 号時の実測結果と比較した結果を示す。 台風 8218 号時の風速のスペクトルをFig.4.2に， 風洞実験により得られた変動風圧保数および風速 


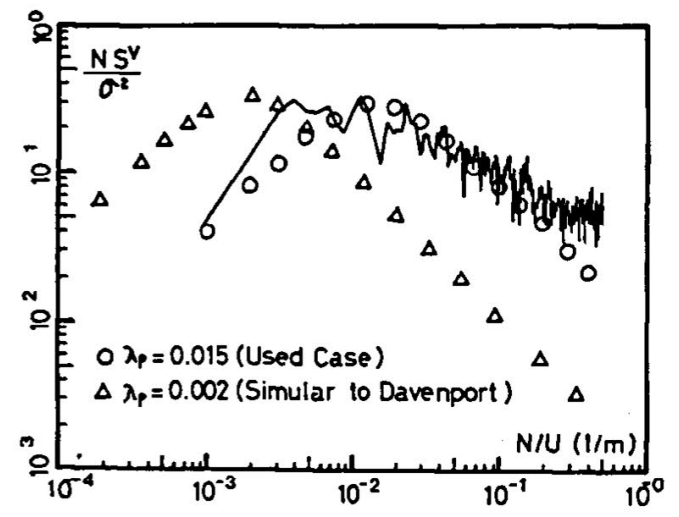

Fig.4.2 台風 8218 号の風速のスペクトル

(Power spectrum density of wind speed, typhoon 8218 )

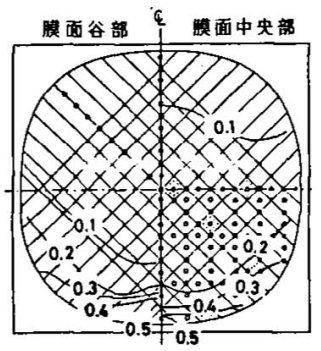

口

（b）变野風压俰分布

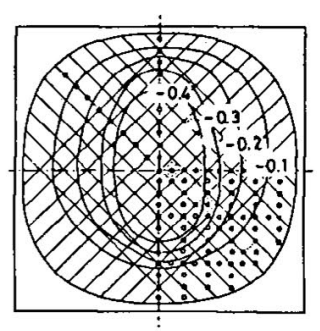

$\stackrel{1}{\square}$

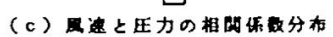

Fig.4. 3 変動風圧に関する風洞実験結果

(Results of wind tunnel tests of dynamic pressure distribution)

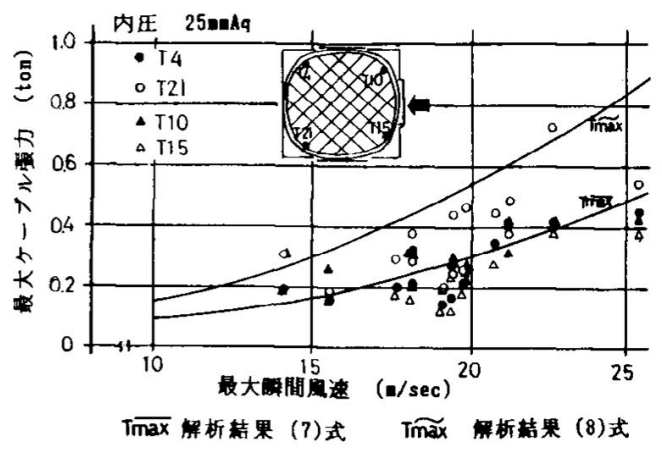

Fig.4.4 最大瞬間風速とケーブル張力の関係

(Relation between maximum cable tensions and gust wind speed)
と圧力の相関係数を Fig.4.3 に示す（平均風圧係 数は Fig. 3.4 参照，また， $k x=2, k y=12, \beta=1$, $n o=16$ とした)。これらの条件を本解析法に適用 し，2.1 節で示した，ケーブル張力は風荷重に比 例する関係を用いてケープ几最大張力を求め，実 測結果と比較した結果をFig.4. 4 亿示す。図より 平均風圧保数を使用した場合は最大張力の極限値 的值を示し，相関係数を䓕入した变動風王係数を 使用した場合は期待値的値を示していることがわ かる。

2）屋根面の耐風店、答解析

本構造の屋根面は，平面的広がりを有しており， 本解析法ではその影慜を前節と同梯(4) (6)式の形 で考剫する。

解析モデルをFig.4.5 亿示す。

運動方程式は次式で表現できる。

$$
\begin{aligned}
& {[m]\{\ddot{z}\}+[c]\{\dot{z}\}+[k]\{z\}=\{f\}} \\
& f j=\sum_{\ell j}^{N} \rho \mathrm{V}_{j, \ell j} v_{j, \ell j} \mathrm{C} \sigma_{j, \ell j} \mathrm{~A}_{j, \ell j}
\end{aligned}
$$

ことに, $m$ : 質量, $c$ : 娍衰係数, $k$ : 剛性, $f:$ 荷重, $z, \dot{z}, \ddot{z}:$ 応答変位, 速度, 加速度, $v:$ 気流の乱机成分

(12)式をフーリェ変換し，モード分離すると庆答 変位のスペクトル $\mathrm{S}_{z}(n)$ は次式で表わせる。

$[\mathrm{S} z]=(\mathrm{X})\left(\mathrm{H}^{*}\right](\mathrm{X})^{\mathrm{T}}\left[\mathrm{S}^{f}\right)(\mathrm{X})(\mathrm{H})(\mathrm{X})^{\mathrm{T}}$

$$
\begin{aligned}
{\left[\mathrm{S}^{f}\right]=} & {\left[\sum_{\ell i=1}^{\mathrm{N} i} \sum_{\ell j=1}^{\mathrm{N} j} \rho^{2} \mathrm{~V}_{i, \ell i} \mathrm{~V}_{j, \ell j} \mathrm{C}_{\sigma_{i}, \ell i} \mathrm{C}_{\sigma j \ell j}\right.} \\
& \left.\mathrm{A}_{i \ell i} \mathrm{~A}_{j \ell j} \mathrm{~S}_{i j, \ell i \ell j}{ }^{\mathrm{V}}\right]
\end{aligned}
$$

ここで, $\mathrm{H}$ : 伝達関数, $\mathrm{X}$ : 固有マトリックス

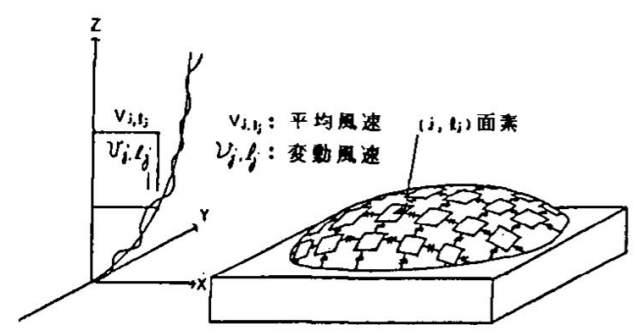

Fig.4. 5 解析モデル

(Model for analysis) 
以上より， $i$ 質点の最大応答夜位 $Z_{\max }, i$ は次式 で定義できる。

$$
\begin{aligned}
& \mathrm{Z} \max , i=\bar{Z}_{i}+\mathrm{P}_{i} \sigma_{z, i} \\
& \sigma_{z, i}^{2}=\int_{-\infty}^{\infty} \mathrm{S}_{z, i}(n) d n \\
& \mathrm{P}_{i}=\sqrt{2 \ln \nu \mathrm{T}}+0.5776 / \sqrt{2 \ell n \nu \mathrm{T}} \\
& \nu=\sqrt{\int_{-\infty}^{\infty} n^{2} \mathrm{~S}_{z, i}(n) d n / \int_{-\infty}^{\infty} \mathrm{S}_{z, i}(n) d n}
\end{aligned}
$$

ととに， $\bar{Z}_{i}$ : 平均応答変位, また風速のスペク トルを, $\frac{n \mathrm{~S}^{\mathrm{V}}}{\sigma_{\mathrm{V}}^{2}}=\frac{1}{\pi} \frac{\lambda_{p} \mathrm{~V} n}{n^{2}+\left(\lambda_{p} \mathrm{~V}\right)^{2}}$

$\lambda_{p}:$ スペクトルのピーク波数

で表現すると, 最大纫答変位は留数積分を利用し 解析的に求めるととができる。

次に, 本耐風応答解析法を大規模試験体に適用 し, 台風 8218 号時の実測結果と比較した結果を 示す。使用した固有值は, 内压 $25 \mathrm{mmAq}$, 平均風 速 $12.4 \mathrm{~m} / \mathrm{s}$ 相当時の剈性を用いて評価した。応 答解析に用いた固有振動数は風速のスペクトルを 考虑した刺激係数を参考にその採用次数を決定し た。その他の条件は前記風荷重の算定に示す值に よった。なお, 風圧係数は, 相関係数を導入した 変動風圧係数を用いている。

台風 8218 号時の実測結果之解析結果の一例

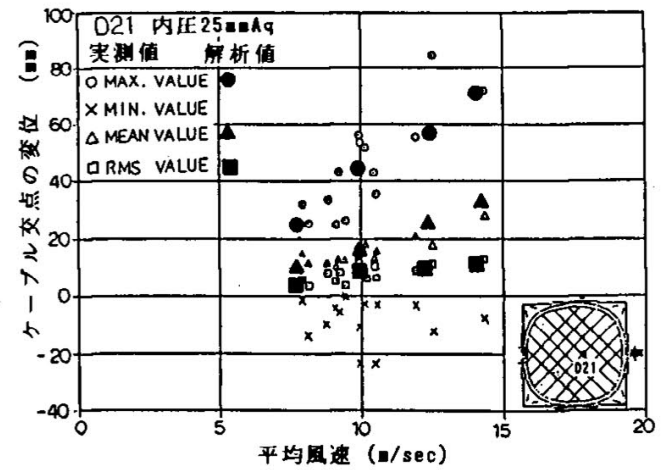

Fig.4.6 屋根面の振動变位（実測と解析結果の 比較 )

(Relation between deflections and mean wind speed)
をFig.4.6 亿示す。図より，解析結果は，台風時 の振動性状を概略説明しているすのと判断できる。

\section{5. まとめ}

低ライズケーブル補強空気膜構造に関する大規 模な野外実験，風洞実験および解析により，耐風 設計に必要な各種の資料を得た。それらの結果を まとめ以下に示す。

）屋根面に作用する風荷重分布には変形の生じ やすい分布形状の成分が含まれているため，変 形は風荷重を等分布荷重に換算した場合に比べ て大きくなる。

ii）張力は変位と比較して荷重の偏在による影響 を受りにくく，同一ヶーブル両端では同程度の 張力値を示し，その值は風荷重に比例する。

iii）強風時の屋根面の振動は体積変化のない，ま たケーブル長の変化を伴わない低次のモードに よる振動が主である。

iv）内压を高めるととは，強風時の変形を抑制す る有効な手段である。

v）内压の上昇江伴い，固有振動数は増加し，减 衰定数は减少する。

VI) 平均風圧保数に関し，風洞実験結果は実測結 果と良い対応を示しており，剛体模型を用いた 風洞実験により風压力を推定するととができる。 VID 屋根のライズ/スパン比の増加により, 膜面 の最大，最小風王係数の差は大きくなる。また， 全体の平均的な風圧力も増加する。

ViiD 屋根面に凹凸のある本構造の特徽として, 膜 パネル中央部の風王係数は谷部の值より大きく， 膜パネル全体に作用する風圧力は平均すると中 央部の約 0.85 倍程度となる。

Ｘ）屋根面に作用する風荷重および振動変位は， 風洞実験加ら得られた平均風区俰数, 变動風圧 係数および風速と压力の相関係数を用い，準静 的理論を応用した確率統計的解析手法により予 測するととができる。 
参考文献

1) ニューマチック構造（空気膜構造）設計基準, 建設省住宅局建築指導課

2) 大規模空気膜構造建築物の評価基準，日本建 築センタ一, 昭和 59 年 12 月

3）川村純夫, 他; ニューマチック構造の耐風性 に関する研究 (その1) (その6), 日本建 築学会近䪵支部研究報告集, 昭和 53 年, 日本 建築学会大会梗概集, 昭和 53 年, 54 年, 55 年, 56 年。

4）川村純夫, 室田達郎, 木本英爾, 昇高㴡; 空 気膜構造の実験報告 $\mathrm{V}$ (EXPO-70’アメリカ館 一振動性状之耐風安定性), 日本建築学会大会 梗概集。昭和 45 年 9 月, $617-618$

5) B.V.Tryggvason; Aeroelastic modeling of pneumatic and tensioned fablic structures, 5 th international conference on winb engineering , 1979 , viii- 8-1 12

6）又木義浩, 岩佐義輝, 林田英俊, 芳野釈子; 低ライズケーブル補強空気膜構造に作用する風 王力について, 平均風压係数の性状, 日本建築 学会大会梗概集。昭和 59 年1 0月, 2619-2620

7）対馬義幸, 岩佐義輝, 真柄栄毅、又木義浩, 深尾康三, 岡田章, 林田英俊, 藤本康和; 低亏 イズケープル補強空気膜構造の力学性状に関す る実験的研究その $1 \sim$ その 4 , 日本建築学会大 会梗概集 昭和 59 年1 0月, $2633 \sim 2640$

8）深尾康三，岩佐義輝，又木義浩，岡田章；低 ライズケーブル補強空気膜構造の力学性状に関 する実験的研究, 風圧力の性状と風荷重時の静 力学特性について, 第 8 回風工学シンポシゥム, 1984 年1 2月, $137-144$

9）又木義浩, 岩佐義輝, 深尾康三; 高層建物の バフェッティンク振動の解析に関する研究, 多 面素, 多質点系人の拡張, 日本建築学会大会梗 概集、昭和 52 年1 0月, $929-930$

10) Takeo Mori; On dynamic response of a f lat long-span roof to action of wind, 日本建築学会論文報告集 第2 41 号, 昭和 51 年 3 月, $91-109$

11) D.E.Cartwright, $M, S$, Longuet-Higgins, The statistical distribution of the maxima of a randam function, Proc.Roy.Soc. vol $237,1956,212-232$ 